\title{
Clusia falcata (Clusiaceae), an endangered species with exceptionally narrow leaves endemic to Chiapas, Mexico
}

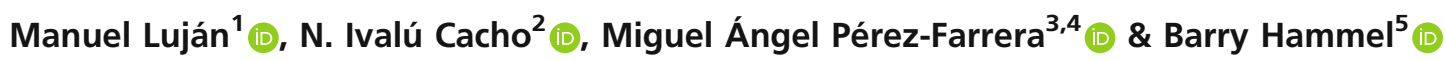

Summary. Clusia falcata (Clusiaceae), a new species from Chiapas, Mexico, is described and illustrated. This new taxon is distinctive for its leaves, among the narrowest of all known species, having lanceolate to oblong laminas that are mostly $10-15 \times 2-2.5 \mathrm{~cm}$. The flowers have a quadrangular perianth with succulent petals, and a nonresiniferous androecium and gynoecium. Staminate flowers have a quadrangular androphore bearing $18-24$ short stamens. Pistillate flowers have 4 pairs of staminodia, with each pair born on an androphore. The species is endemic to montane forests of the Northern and Eastern highlands of Chiapas in Mexico and is currently considered to be endangered.

Resumen. Clusia falcata (Clusiaceae), una nueva especie de Chiapas, México, es descrita e ilustrada. Este nuevo taxón se distingue por sus hojas entre las más angostas de todas las especies conocidas, con láminas lanceoladas a oblongas, generalmente de $10-15 \times 2-2.5 \mathrm{~cm}$. Las flores tienen un perianto cuadrangular con pétalos suculentos y androceo y gineceo no resiníferos. Las flores estaminadas tienen un andróforo cuadrangular con 18 - 24 estambres cortos. Las flores pistiladas tienen 4 pares de estaminodios, cada par sobre un andróforo. La especie es endémica de bosques de las montañas del norte y este de Chiapas en México y se considera en peligro de extinción. La especie es endémica de los bosques mesófilos de montaña en las tierras altas al este y norte de Chiapas en México y se considera en peligro de extinción.

Key Words. Neotropics, new species, taxonomy, tropical trees.

\section{Introduction}

Clusia L. (Clusiaceae) comprises $300-400$ species of hemiepiphytic or terrestrial shrubs and trees distributed from Mexico and the Greater Antilles to Bolivia and southeastern Brazil (Gustafsson et al. 2007). According to molecular evidence the genus is a strongly-supported monophyletic group (Gustafsson \& Bittrich 2002; Gustafsson et al. 2007; Luján 2019). One consistent morphological synapomorphy for the genus is the presence of a two- to many-layered hypodermis in the leaves (Vesque 1892; Luján pers. obs.). Other characters that are common across Clusia species and that help distinguish it from related genera are fruits with more than one seed per carpel, seed length $\leq 5 \mathrm{~mm}$ and non-vascularised seed aril (Gustafsson et al. 2007).

At least 13 species of Clusia have been reported from Mexico, most of them distributed in montane forests in the southern states of Chiapas, Oaxaca and Veracruz (Tellez et al. 2020). The most widespread species in the country, C. salvinii Donn.Sm. is common in mid- to high-elevation cloud forests and has been collected up to the northwestern state of Sinaloa (Rzedowski \& Zamudio 2001). The range of $C$. salvinii probably represents the latitudinal northern extreme of the natural distribution of the genus in continental America, except for some populations of C. rosea Jacq. in southern Florida, although the range of the latter species is likely influenced by its common cultivation and subsequent naturalisation. Before this study, two species of Clusia were considered endemic to Mexico, namely C. pringlei Lundell, distributed in mid-elevation montane forests of the trans-Mexican volcanic belt and Sierra Madre del Sur, and C. tetratrianthera Maguire, which occurs in low to mid-elevation forests in central Chiapas and Veracruz (Maguire 1979).

As part of an ongoing taxonomic revision of Clusia for Mexico, a set of specimens were identified as

\footnotetext{
Accepted for publication 8 September 2021. Published online 11 December 2021

1 Royal Botanic Gardens, Kew, Surrey TW9 3AE, Richmond, UK. e-mail: m.lujan@kew.org

2 Instituto de Biología, Universidad Nacional Autónoma de México, Circuito Exterior, Ciudad Universitaria, Mexico City, 04510, México.

3 Herbario Eizi Matuda, Laboratorio de Ecología Evolutiva, Instituto de Ciencias Biológicas, Universidad de Ciencias y Artes de Chiapas, Tuxtla Gutiérrez, México.

4 Facultad de Ciencias Naturales, Universidad Autónoma de Querétaro, Ave. De las Ciencias S/N, Juriquilla, 76230, Santa Rosa Jáuregui, Querétaro, México.

5 Missouri Botanical Garden, 4344 Shaw Blvd., St. Louis, MO 63110, USA.
} 
representatives of a distinct yet undescribed taxon. Here we provide a description for this new species along with a discussion of its morphological affinities to other taxa in the genus.

\section{Materials and Methods}

Herbarium specimens were studied at CAS, CR, MEXU and MO (acronyms follow Thiers, continuously updated) using dissecting stereoscopes. We applied the unified species concept from de Queiroz (2007) in which species are interpreted as separate evolving lineages based on their defining properties. In this case, phenotypic diagnosability and geographic distribution were used as lines of evidence for lineage separation. We followed the terminology of Beentje (2016) to describe morphological characters. Species conservation status was assessed following the IUCN red list categories and criteria (2019). The GeoCat tool (Bachman et al. 2011), with a cell width of $2 \mathrm{~km}$, was used to estimate extent of occurrence (EOO) and area of occupancy (AOO).

\section{Taxonomic Treatment}

Clusia falcata Hammel sp. nov. Type: Mexico. Chiapas: Municipio Jitotol, along Río Hondo, $6.5 \mathrm{~km} \mathrm{~N}$ of Jitotol along road to Pichucalco, $1700 \mathrm{~m}, 27$ Oct. 1971, D. E. Breedlove E R. F. Thorne 21392 (ठ) (holotype: MO! barcode 2611409; isotypes: CAS! 330944, MEXU! 254952).

http://www.ipni.org/urn:lsid:ipni.org:names:77220442-1

Free-standing or hemiepiphyte shrub, 3-8 m; dioecious; branches cylindrical, epidermis non exfoliating; resin greenish-white. Leaves with the petiole $1.5-1.8 \mathrm{~cm}$, unwinged, the base excavated and forming a pit in the adaxial portion of the junction between the petiole and the stem; lamina drying dark brown adaxially and light brown abaxially, $(8-) 10-15.5 \times(1.4-) 2-2.5 \mathrm{~cm}$, narrowly lanceolate to oblong or elliptic, often falcate, base attenuate, apex acute to acuminate, margin slightly revolute; venation pinnate brochidodromous, the principal secondary veins $5-8$ pairs, $5-10 \mathrm{~mm}$ apart, forming a $20^{\circ}-30^{\circ}$ angle to primary vein, prominent abaxially and flat to slightly prominent adaxially; primary vein evident along the entire length of the lamina, the intramarginal vein $1 \mathrm{~mm}$ from margin; resin canals visible when dry in the adaxial (more faintly so on the abaxial) surface as thin, more or less continuous, nigrescent lines arising at a very narrow angle from, but eventually more or less parallel to the primary vein. Inflorescences slightly deflexed to pendant; dichasia often lacking the central flower, the staminate $4-5 \times 4-8 \mathrm{~cm}$, with $2-3$ ramifications per node and a total of c. 16 flowers, the peduncle $1-3 \mathrm{~cm}$, cylindrical to subquadrate; the pistillate $2-3 \times$ c. $1 \mathrm{~cm}$, with 2 or 3 ramifications per node (or ramifications lacking, but with 2 sets of bracts, c. $1 \mathrm{~cm}$ apart), with $1-5$ flowers; bracts (subtending inflorescence branches) and bracteoles (subtending flowers) paired, $1.5-2 \mathrm{~mm}$, more or less deltate, the apex acute, abaxially keeled. Flower buds $6-10 \mathrm{~mm}$ in diam. Flowers unisexual, lightly, but sweetly aromatic, non-resiniferous, the perianth differentiated into sepals and petals; sepals 4, light green, $5-6$ $\times 3-4 \mathrm{~mm}$ and elliptic (staminate flowers), c. $6 \times 6 \mathrm{~mm}$ and suborbicular (pistillate flowers); petals 4, erect, light green to dark pink, swollen at the base, succulent, $4-6 \times$ $3-5 \mathrm{~mm}$, oblong to pandurate (staminate flowers), c. $9 \times$ $6 \mathrm{~mm}$, ovate to suborbicular (pistillate flowers). Androecium (staminate flowers), uniform, (1.2 -) $1.5-3 \mathrm{~mm}$, the androphore c. $2 \times 2 \mathrm{~mm}$, quadrangular with the sides concave due to bulged petal bases, convex; stamens $22-$ 24 , free, the filaments $(0.2-) 0.5-1 \mathrm{~mm}$, anthers $1-2$ $\mathrm{mm}$, longitudinally dehiscent (Fig. 1). Gynoecium (pistillate flowers) with 4 pairs of stamen-like staminodia, alternate to the petals, c. $4 \mathrm{~mm}$ (including the androphore), each pair borne on an androphore, c. 2.7 mm; stigmas 4, smooth, discoid, sessile. Fruits pale yellow to green when submature, sepals persistent, $4-6 \times 3-$ $3.5 \mathrm{~cm}$ in diam., ellipsoid, 4-locular; seeds and arils not seen.

RECOGNITION. Clusia falcata can be readily separated from its congeners by its narrow lanceolate to oblong leaves $(8-) 10-15.5 \times(1.4-) 2-2.5 \mathrm{~cm}$, with a ratio of leaf width to length of 0.17 , which are likely the narrowest leaves observed in the genus thus far. Certain material of C. dukei Maguire - a species restricted to lowland wet forests on the Atlantic slopes of Costa Rica and Panama - likewise with very narrow and sometimes falcate leaves, has been indicated as worthy of taxonomic recognition (see Hammel 2010). That material has laminas $9.6-15 \times 1.4-3 \mathrm{~cm}$ (leaf width to length ratio of 0.18 ), flowers with similarly 4merous perianth and succulent petals. That form of C. dukei differs from C. falcata by its more numerous secondary veins at a wider angle to the primary vein (12 - 15 pairs, $2-3(-5) \mathrm{mm}$ apart, at $30^{\circ}-40^{\circ}$ angle vs $5-8$ pairs, $5-10 \mathrm{~mm}$ apart, at $20^{\circ}-30^{\circ}$ angle); and by its androecium with more stamens (32 vs $22-24$ in C. falcata). Clusia dukei overall differs by its clear (vs greenish-white) resin, and by its very different configuration of the resin canals, which are relatively short (interrupted) and widely branched lines that sometimes appear to form a mesh, vs the continuous and usually unbranched lines of C. falcata, more like those of C. flava Jacq. and C. guatemalensis Hemsl. These latter two species have flowers with a similar perianth, androecium and gynoecium, but usually with a higher number of stamens, staminodia, and stigmas than in C. falcata. Most notably, their leaves are never as long and narrow as those of C. falcata. 


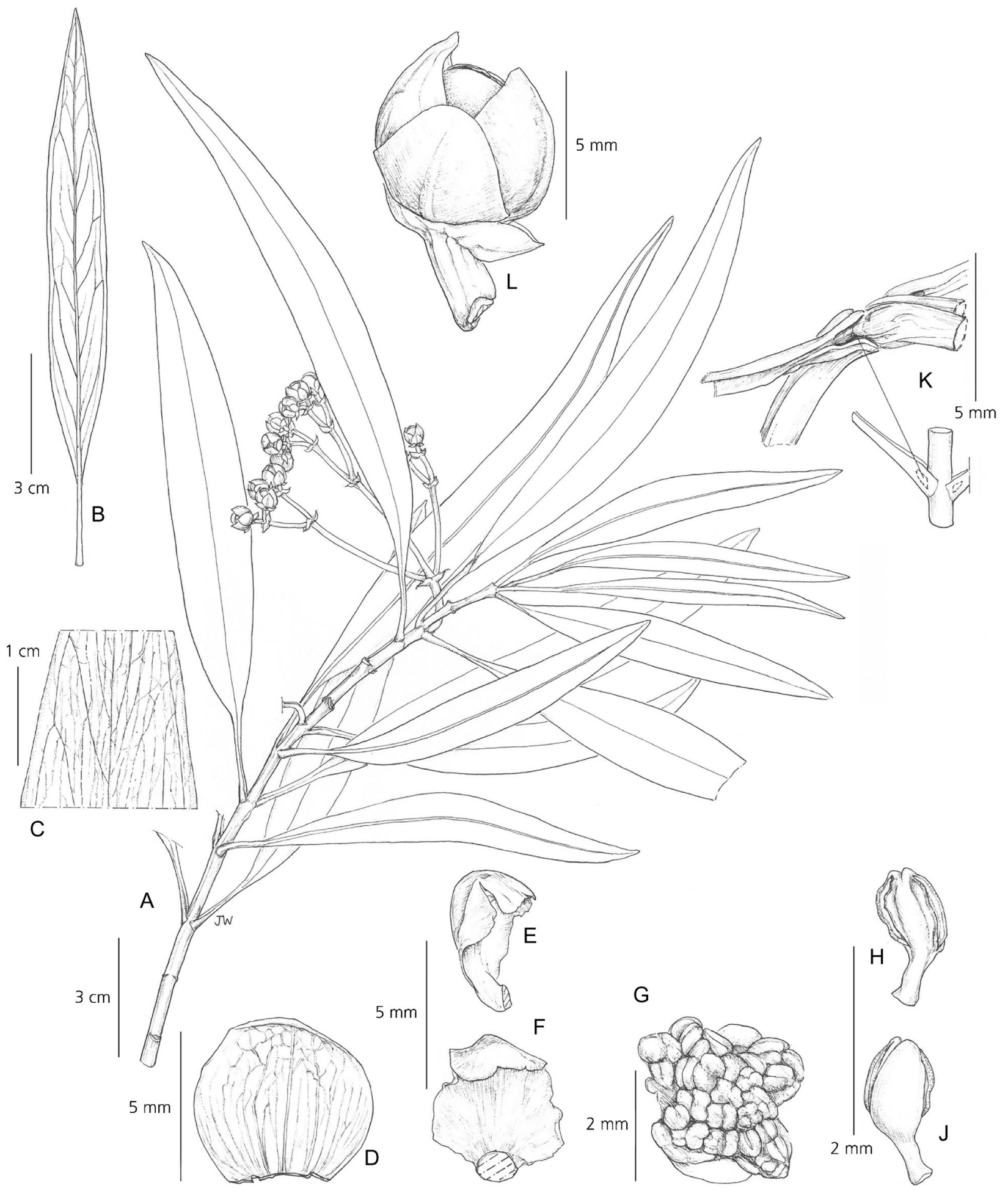

Fig. 1. Clusia falcata. A habit of flowering staminate branch; B leaf showing abaxial surface; $C$ detail of adaxial surface of leaf showing resin canals; D sepal adaxial side; E - F petal side view and adaxial side; G androecium; $\mathrm{H}$ - J stamens; $\mathrm{K}$ detail of petiole base showing pit in the junction with the branch; L staminate flower bud. From D. E. Breedlove \& R. F. Thorne 21392 (holotype, MO). DRAWN BY JULIET BEENTJE.

DISTRIBUTION. Northern and Eastern highlands of Chiapas (Map 1).
SPECIMENS EXAMINED. MeXICO. Chiapas: Municipio Jitotol, along Río Hondo, $6.5 \mathrm{~km} \mathrm{~N}$ of Jitotol along 


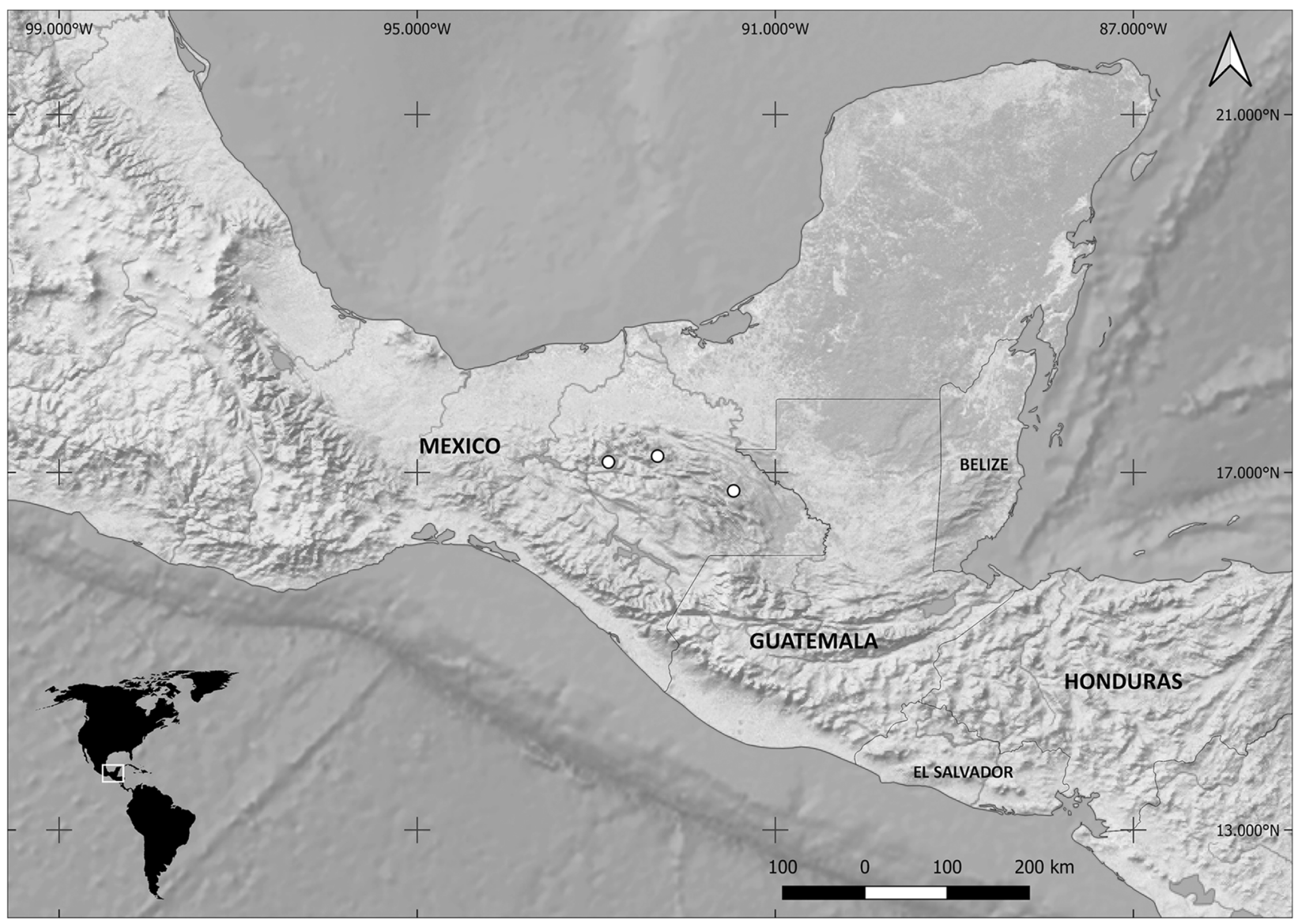

Map 1. Distribution map of Clusia falcata in Chiapas, Mexico.

road to Pichucalco, $1700 \mathrm{~m}, 27$ Oct. 1971, D. E. Breedlove $\mathcal{E}$ R. F. Thorne 21392 (ठ) (holotype: MO! barcode 2611409; isotypes: CAS! 330944, MEXU! 254952). Paratypes: Municipio Ocosingo, limestone area near Laguna Ocotal Grande, c. 25 - 30 km SE of Monte (Cerro) Líbano, which is $43 \mathrm{~km} \mathrm{E}$ of Ocosingo, 950 m, 20 July - 7 Aug. 1954, R. L. Dressler 1689 () (MEXU); Municipio Jitotol, 4 miles $\mathrm{N}$ of Jitotol, on the road to Pueblo Nuevo Solistahuacán, 1676 m, Sept. 1971, R. F. Thorne E E E. Lathrop 41730 (ठ) (CAS); Municipio Yajalón, Banco de Grava, 15 Sept. 1983, A. Méndez Ton 6664 (ठ̋) (MEXU); Municipio Jitotol, $7 \mathrm{~km} \mathrm{~N}$ of Jitotol on road to Pichucalco (highway 195), in woods along river, upstream from bridge, 14 Oct. 1986, B. Hammel, E. Martinez Ẽ M. Merello 15692 (ð̋) 15693 () (CR, MO). HABITAT. Clusia falcata grows on forested slopes with Pinus, Quercus and Liquidambar, and on karst areas in tropical rain forests at $950-1700 \mathrm{~m}$.

CONSERVATION STATUS. We estimate an extent of occurrence (EOO) of $1,569.623 \mathrm{~km}^{2}$ and an area of occupancy (AOO) of $12.0 \mathrm{~km}^{2}$ for Clusia falcata. The species is known from only three localities, and continuous decline in habitat quality is inferred in at least two of them given their proximity to urban centres (the towns of Jitotol and Yajalón respectively). Only one location is within a protected area, the Reserva de Biosfera Montes Azules, which may ensure the long-term stability of that particular plant population. Given the reduced number of known localities and their likely future instability, we assess the conservation status for C. falcata as endangered (EN) based on the IUCN criteria Blab(iii)+2ab(iii).

PHENOLOGY. Clusia falcata was collected with flowers in September and October, and with fruits in August.

ETYMOLOGY. The specific epithet of Clusia falcata derives from the latin word falcatus, which describes the narrow and curved shape of the leaves, a character not previously observed in the genus.

NOTES. With the aim of identifying the phylogenetic position of Clusia falcata, sequencing of nrITS was attempted using tissue from the type specimen, although amplification was unsuccessful, probably because the DNA was highly degraded, which is common in tissues sampled from herbarium specimens. Nevertheless, the presence of a non-resiniferous quadrangular androphore bearing multiple free stamens suggests that C. falcata is included in the "Clusia flava group" an informal infrageneric species assembly that includes C. dukei, C. flava, C. guatemalensis, 
C. lundellii Standl., C. quadrangula Bartlett, C. torresii Standl. and likely other closely related species from Central America with similar androecial morphology (Hammel 1986). According to molecular evidence, the flava group is a well-supported monophyletic group (Gustafsson et al. 2007; Luján 2019) in which hemiepiphytic habit as well as CAM photosynthesis are commonly present (Vargas-Soto et al. 2009), and includes most, although not all taxa originally proposed by Hammel (1986).

A general pattern observed in evergreen woody plants is that relatively small leaves are more common at high latitudes, high elevations, nutrient poor, and hot arid conditions (Givnish 1987; Wright et al. 2017). Moreover, in some groups (e. g. subtropical bamboos), species with relatively narrower leaves tend to inhabit areas subject to water deficiency (Lin et al. 2020). The exceptionally narrow leaves observed in Clusia falcata suggest that this species may tolerate conditions of limited water availability. Furthermore, one specimen of C. falcata (R. L. Dressler 1689 [MEXU]) was collected on a limestone area, which indicates that the species may tolerate soils with high alkalinity and low nutrient levels. Several environmental and genetic factors are involved in determining leaf size and shape, potentially leading to many equally viable leaf strategies for a given environment (Wright et al. 2017). Further comparative research is needed to better understand the drivers of leaf size and shape variability in Clusia, and to test whether $C$. falcata is adapted to particularly harsh environmental conditions.

\section{Acknowledgements}

The authors would like to thank Dr Jim Solomon and Alba Arbelaez for their kind assistance during work at MO, which was supported by Missouri Botanical Garden's Alwyn Gentry Fellowship for Latin American Botanists granted to ML. Emily Magnaghi provided generous assistance during work at CAS. Dr Raquel Negrao kindly revised the species conservation assessment. Juliet Beentje prepared a wonderful botanical illustration. Two anonymous reviewers provided valuable comments and suggestions which greatly improved this manuscript.

Open Access This article is licensed under a Creative Commons Attribution 4.0 International License, which permits use, sharing, adaptation, distribution and reproduction in any medium or format, as long as you give appropriate credit to the original author(s) and the source, provide a link to the Creative Commons licence, and indicate if changes were made. The images or other third party material in this article are included in the article's Creative Commons licence, unless indicated otherwise in a credit line to the material. If material is not included in the article's Creative Commons licence and your intended use is not permitted by statutory regulation or exceeds the permitted use, you will need to obtain permission directly from the copyright holder. To view a copy of this licence, visit http://creativecommons.org/ licenses/by/4.0/.

\section{References}

Bachman, S., Moat, J., Hill, A., de la Torre, J. \& Scott, B. (2011). Supporting Red List threat assessments with GeoCAT: geospatial conservation assessment tool. ZooKeys 150. https://doi.org/10.3897/zookeys.150.2109

Beentje, H. (2016). The Kew Plant Glossary an illustrated dictionary of plant terms (2nd edn). Royal Botanical Gardens, Kew.

De Queiroz, K. (2007). Species Concepts and Species Delimitation. Syst. Biol. 56: 879 - 886. https://doi.org/ 10.1080/10635150701701083

Givnish, T. J. (1987). Comparative studies of leaf form: assessing the relative roles of selective pressures and phylogenetic constraints. New Phytol. 106: 131 - 160. https://doi.org/10.1111/j.1469-8137.1987.tb04687.x

Gustafsson, M. H. G. \& Bittrich, V. (2002). Evolution of morphological diversity and resin secretion in flowers of Clusia (Clusiaceae): insights from ITS sequence variation. Nord. J. Bot. 22: 183 - 203. https://doi.org/ 10.1111/j.1756-1051.2002.tb01364.x

Winter, K. \& Bittrich, V. (2007). Diversity, Phylogeny and Classification of Clusia. Pp. 95 - 116. In: U. Luttge (ed.), Chusia A Woody Neotropical Genus of Remarkable Plasticity and Diversity. Springer, Berlin, Heidelberg. https://doi.org/10.1007/978-3-540-37243-1_7.

Hammel, B. E. (1986). New species of Clusiaceae from Central America with notes on Clusia and synonymy in the tribe Clusieae. Selbyana 9: $112-120$.

(2010). Clusiaceae. Pp. 1 - 54 In: B. E. Hammel, M. H. Grayum, C. Herrera \& N. Zamora (eds), Manual de plantas de Costa Rica Vol. V. Monogr. Syst. Bot. Missouri Bot. Gard. 119: $1-970$.

IUCN Standards and Petitions Committee (2019). Guidelines for Using the IUCN Red List Categories and Criteria. Version 14. Prepared by the Standards and Petitions Committee. Downloadable from http://www. iucnredlist.org/documents/RedListGuidelines.pdf. [Accessed 28 May 2021].

Lin, S., Niklas, K. J., Wan, Y., Hölscher, D., Hui, C., Ding, Y. \& Shi, P. (2020). Leaf shape influences the scaling of leaf dry mass vs. area: a test case using bamboos. Ann. Forest Sci. 77: 1 - 15. https:// doi.org/10.1007/s13595-019-0911-2

Luján, M. (2019). Playing the Taxonomic Cupid: Matching Pistillate and Staminate Conspecifics in Dioecious Clusia (Clusiaceae). Syst. Bot. 44: 548 - 559. https://doi.org/ $10.1600 / 036364419 \times 15620113920590$ 
Maguire, B. (1979). On the genus Chusia (Clusiaceae) in Mexico. Taxon 28: 1 - 3. https://doi.org/10.2307/1219548

Rzedowski, J. \& Zamudio, S. (2001). Etapa final de la captura y catalogación del Herbario del Instituto de Ecología A. C., Centro Regional del Bajío. Herbario IEB. Centro Regional del Bajío. Bases de datos SNIB-CONABIO, proyectos HA010, FS002, Q017, J097 y F014. México, D. F.

Tellez, O., Mattana, E., Diazgranados, M., Kühn, N., Castillo-Lorenzo, E., Lira, R., Montes-Leyva, L., Rodriguez, I., Flores Ortiz, C. M., Way, M., Dávila, P. \& Ulian, T. (2020). Native trees of Mexico: diversity, distribution, uses and conservation. PeerJ 8, e9898. https://doi.org/10.7717/peerj.9898

Thiers, B. (continuously updated). Index herbariorum: a global directory of public herbaria and associated staff. New York Botanical Garden's virtual herbarium. Published at http://sweetgum.nybg.org/science/ih/. [Accessed 30 April 2018].
Vargas-Soto, J. G., Andrade, J. L. \& Winter, K. (2009). Carbon isotope composition and mode of photosynthesis in Clusia species from Mexico. Photosynthetica 47: 33 40. https://doi.org/10.1007/s11099-009-0007-6

Vesque, J. (1892). Epharmosis, sive materiae ad instruendam anatomiam systematis naturalis. 3. Genitalia foliaque Clusiearum et Moronobearum. J. Vesque (ed.); Vol. 3. Delapierre, Vincennes.

Wright, I. J., Dong, N., Maire, V., Prentice, I. C., Westoby, M., Díaz, S., Gallagher, R. V., Jacobs, B. F., Kooyman, R., Law, E. A. \& Leishman, M. R. (2017). Global climatic drivers of leaf size. Science 357 (6354): 917 - 921. https:/ / doi.org/10.1126/science.aal4760

\section{Publisher's Note}

Springer Nature remains neutral with regard to jurisdictional claims in published maps and institutional affiliations. 